\title{
How to Deal with Negative Publicity: the Importance of Consumer Involvement
}

\author{
Celso Augusto de Matos \\ Ricardo Teixeira Veiga
}

\begin{abstract}
RESUMO
Informações negativas sobre empresas podem ter um efeito nocivo nas percepções dos consumidores. Entretanto, poucos estudos investigam como os consumidores processam as informações negativas e como as empresas deveriam reagir a elas. Com o objetivo de examinar essa questão, dois experimentos foram realizados: primeiro, um experimento de laboratório que testa como os consumidores processam dois tipos de publicidade negativa (ligada a atributos do produto ou a valores da empresa); segundo, um experimento de campo, que compara três tipos de reações da empresa afetada pela publicidade negativa (nenhuma resposta, negação/redução do impacto negativo e ação corretiva). Os resultados do primeiro estudo confirmaram o efeito nocivo da publicidade negativa nas atitudes dos consumidores, indicaram que os consumidores possuem maior nível de envolvimento com a mensagem quando ela é voltada para os valores da empresa e sugeriram um efeito moderador da variável envolvimento com o produto na relação entre a informação negativa e a imagem da empresa. $\mathrm{O}$ segundo experimento estende esses resultados ao testar empiricamente diferentes alternativas de reação da empresa à publicidade negativa identificadas previamente na literatura. Os resultados sugeriram novamente a variável envolvimento como moderadora, sendo na relação entre reação da empresa e imagem do produto.
\end{abstract}

Palavras-chave: publicidade negativa; reação da empresa; atitudes; envolvimento; experimento.

\begin{abstract}
Negative information about companies can have a harmful effect on consumer perceptions. However, few studies investigate how consumers process negative publicity and how companies should react to it. In order to examine this question, two experiments were carried out: first, a laboratory experiment which tests how consumers process two different types of negative publicity (product attributes or company values); second, a field experiment comparing three different responses (no answer, denial/reduction of offensiveness and corrective action) given by the company affected by the negative publicity. Results from the first study confirm the detrimental effect of negative publicity on consumer attitudes, indicate that consumers have a higher level of involvement with the message when it is concerned with the company's values and suggest a moderating role of the product involvement on the influence of negative information on corporate image. The second study extends these findings by identifying different options for company reactions from literature and testing them empirically. Results suggest again the involvement variable as a moderator, now on the influence of company reaction on product image.
\end{abstract}

Key words: negative publicity; company reaction; attitudes; involvement; experiment. 


\section{INTRODUCTION}

The greater weight of negative information compared to its positive counterpart is a phenomenon that has already been investigated in the area of Psychology, especially in impression formation subject (FISKE, 1980). Studies in consumer behavior have shown that there is greater efficacy in negative framing of a message (Maheswaran and Meyers-Levy, 1990) and that negative news about companies, so called negative publicity, can affect consumer's perceptions as well as their behavior (AHLUWALIA; BURNKRANT; UNNAVA, 2000; GRIFFIN; BABIN; ATTAWAY, 1991; MENON; JEWEL; UNNAVA, 1999).

Given that the main studies dealing with negative publicity have been restricted to the ability domain (i.e., product attributes), such as the one of Ahluwalia and colleagues (2000), this paper also aims to investigate another type of negative publicity, which is in the morality domain (i.e. company values). There are suggestions in the literature that the relevance and usefulness of information that leads to the consumers' final decision is greater in this second type of negative publicity (SKOWRONSKI; CARLSTON, 1987).

The first experiment manipulates negative publicity in two levels (i.e. product information and company information) and tests how consumers perceive these different levels and how involvement affects this process. The second experiment extends the first by manipulating also company reaction to the problem. Finally, we discuss the results comparing them with previous studies, presenting the contributions and limitations of the current study and considering the implications for future research.

\section{THEORETICAL BACKGROUND}

Negative Publicity. Previous research has investigated how people deal with positive $\mathrm{x}$ negative information, especially in the impression formation inquiries in social psychology (FISKE, 1980; SKOWRONSKI; CARLSTON, 1989). These studies have investigated the influence of the negative or positive content of a message on the subject's perception. A common result of these studies is the "negativity effect" in which greater importance is given to negative than to positive information in the general evaluation of a given object (MIZERSKI, 1982). Thus, for the given content of a message, the negative framing is more effective than the positive. One reason for this is that negative information is considered to have a greater capacity to inform in comparison to its positive counterpart (MAHESWARAN; MAYERS-LEVY, 1990).

In this context, negative publicity is defined as "...the noncompensated dissemination of potentially damaging information by presenting disparaging news about a product, service business unit, or individual in print or broadcast media or by word-of-mouth" (REIDENBACH; FESTERVAND; MACWILLIAM, 1987, p. 9).

Negative publicity can be related to either a particular product or a company in general. Analogously, the consumer may have a favorable (unfavorable) attitude toward the product but an unfavorable (favorable) attitude toward the company (REIDENBACH; FESTERVAND; MACWILLIAM, 1987). An event related to a product is that which involves specific attributes of the brand or product, like defects for example, and can place in question the ability of the brand to meet functional needs. On the other hand, an event related to the company values is that which does not involve specific product attributes nor affect its functional use, like social questions or ethical dilemmas faced by the companies, for instance. 
Results obtained in recent studies performed by Ahluwalia, Burnkrant and Unnava, (2000) refer to negative information about the product, creating a subsequent need to expand this negative publicity in relation to the values of the company itself. Thereby, it is assumed that:

$\mathrm{H}_{1}$ : Consumers receiving negative publicity about the product or the company will have lower attitudes if compared to those receiving no information.

However, the harmful effect of negative publicity can be lessened or moderated by other variables such as what the consumer knows about the company, his/her experience with the company as well as his/her degree of loyalty and commitment (AHLUWALIA; BURNKRANT; UNNAVA, 2000). These authors distinguish the moderator role of commitment, emphasizing that the pattern of responses from highly dedicated and moderately committed consumers differs greatly: the former argue against the negative information received, resisting the persuasion of the message, while the latter are more propitious toward a change in attitude.

Involvement. This concept is defined by the personal relevance given to an object (PETTY; CACIOPPO, 1981). Research covering involvement frequently has the objective of evaluating changes in attitude (persuasion) as well as the consistency between attitude and behavior, in other words, in which situations do intentions give way to action.

One distinction must be made between two types of involvement: (i) enduring involvement, related to the personal interests of the consumer; and (ii) situational involvement, more heavily influenced by situational factors which arise when making decisions on purchases (Celsi and Olson, 1988).

In the context of negative publicity, two main types of involvement can be observed: the consumer's involvement with a specific product which has been the target of negative news, which is considered enduring involvement, and the consumer's involvement with the negative information, considered situational involvement because it is related to the importance attributed to this news, the credibility of the source, etc.

The literature also indicates that the degree of relevance perceived in the negative information tends to be greater when it refers to moral aspects, such as company values (SKOWRONSKI; CARLSTON, 1987). In this context, involvement with the negative publicity will tend to be greater for consumers who received negative publicity about a company in comparison to negative publicity about a product. Thus, it can be assumed that:

$\mathrm{H}_{2}$ : Involvement with the negative message will be higher for the negative publicity about the company when compared to the negative publicity about the product.

Involvement can also be a moderator in the persuasion process. According to Petty and Cacioppo (1981, p. 255), persuasion occurs in two manners. The first is called central route because "...the message recipient attends to the message arguments, attempts to understand them, and then evaluates them...the person then integrates all of this information into a coherent and reasoned position." The second, peripheral route, occurs when "... attitude change is determined by such factors as the rewards or punishments with which the message is associated, or the judgmental distortions that take place in perceiving the message or the simple inferences that a person draws about why a speaker advocated a certain position." In this way, attitude change is the result of peripheral persuasion cues, which are "...factors or motives inherent in the persuasion setting that are sufficient to produce an initial attitude change without any active thinking about the attributes of the issue or the object under consideration".

It is important to note that these two routes are the ends of the continuum in the Elaboration Likelihood Model (ELM). Moreover, the level of elaboration is dependent on two conditions: motivation (involvement) and ability. This article assumes that ability is met and only addresses motivation. So, it is assumed that for consumers with a low (high) level of involvement with the product, negative publicity will generate greater (lesser) harm to attitudes, because consumers highly 
involved with an issue tend to counter argue the information received that is against that issue, i.e., a high level of involvement is directly linked to a high resistance to persuasion. So, it is presumed that:

$\mathrm{H}_{3}$ : Negative publicity generates lower attitudes in consumers with lower involvement with the product in comparison to those with higher involvement.

Attitudes. The most widely accepted definition of attitude conceives of it as an evaluation (BAGOZZI; GÜRHAN-CANLI; PRIESTER, 2002), for example: “. ... p psychological tendency that is expressed by evaluating a particular entity with some degree of favor or disfavor" (EAGLY; CHAIKEN, 1993, p. 1).

Attitudes are often considered as a construct composed of three dimensions or components (EAGLY; CHAIKEN, 1993). The cognitive dimension represents an individual's knowledge or thoughts about an object. These thoughts are also considered as beliefs, which are the associations people create between the object and its various characteristics or attributes (FISHBEIN; AJZEN, 1975). The affective dimension consists of feelings, moods and emotions people experience in relation to the object. While some authors consider affect and evaluation interchangeably (FISHBEIN; AJZEN, 1975; ZAJONC; MARKUS, 1982) others regard evaluation and affect as conceptually different (EAGLY; CHAIKEN, 1993). Finally, the behavioral dimension includes the overt actions and intentions that one may have in relation to the object, like buying a brand that one likes or giving positive/negative word-of-mouth about this brand.

These theoretical dimensions of evaluative responses have been submitted to a number of empirical tests, but have not produced a conclusive result. Eagly and Chaiken (1993, p. 13) argues that dimensionality may vary if the attitude object is presented directly or indirectly, and if the response measures are verbal or nonverbal, but in general "...evidence supports the empirical separability of three classes of evaluative responses under some but not all circumstances... and that dimensionality of attitudinal responses thus remains an important issue for empirical and theoretical development".

In this article, we do not test whether the three-dimension model of the attitude concept is valid or not, but only consider the existence of these dimensions, regarding affect and evaluation as one dimension (FISHBEIN; AJZEN, 1975) and behavioral intention as the other. The reason is that the main objective was to evaluate how consumers react to negative publicity in terms of company image, product image and behavioral intentions.

\section{EXPERIMENT 1}

\section{Method}

Stimuli and Independent Variables. A laboratory experiment with two experimental and one control group was conducted. Dependent variables were measured only after the stimulus. The product affected by negative publicity in the experiment was the cellular telephone, more specifically, a leading brand name in the marketplace, referred in this paper by the fictitious name of XYZ. The choice of the cellular telephone is due to its recently increasing market penetration worldwide, the relatively easy switch among cellular telephone companies (i.e. service) and brands of cellular telephone (i.e. equipment) by consumers.

Because of the difficulties in getting a list of owners by the companies in this sector, a nonprobabilistic, by convenience sample was used to reach the cell phone users. However, they were of the type considered as 'non-traditional' (JAMES; SONNER, 2001), composed of MBA students, because of their experience with the target product.

Stimuli used consisted of two news reports. One referred to a published letter from a consumer complaining about having bought a XYZ brand cell phone that had presented successive defects. The 
other news report was linked to the values of the XYZ company, stating that the company had an extremely limited environmental conduct. This report was adapted, not published; however, it was presented as being from the same news source about the product. Pre-tests had showed before that there was no significant difference in perception of subjects concerning the two news reports in terms of the probability of the reports actually having been published.

Procedures. Subjects were randomly assigned into one of the three groups and, before reading the negative information, they answered some preliminary questions about whether or not they owned a cell phone, which brand, if they knew of the XYZ brand of cell phones. Then, they answered 4 items in 7 point Likert scale evaluating their level of involvement with the cellular product, namely I consider the cell phone an important product, I am interested in the cell phone product, The cell phone is a necessary product and The cell phone means a lot to me. These items were chosen in order to represent the overall meaning of involvement used in this study: "a person's perceived relevance of the object based on inherent needs, values, and interests" (ZAICHKOWSKY, 1985, p. 342), which is similar to the definition presented before by Petty and Cacioppo (1981), namely, personal relevance given to an object. Another facets for the involvement construct are also found in the literature, such as risk importance and risk probability (see for example LAURENT; KAPFERER, 1985; JAIN; SRINIVASAN, 1990, for more details).

Finally, subjects read the stimulus and answered to the dependent variables. Before leaving, they received a debriefing message explaining the real purposes of the research.

Dependent Variables. Consumer attitudes were measured by: four items for company image, in a semantic differential scale, namely inferior image - superior image, obsolete company - modern company, socially irresponsible - socially responsible, a brand that I will not try - a brand that I will try; four items for product image, in a semantic differential scale, namely low quality- high quality, not useful - useful, cost doesn't compensate - cost compensate, unreliable - reliable. These items used for product and company image were adapted from Maheswaran and Sternthal (1990). Four items were used to measure behavioral intentions, adapted from Zeithaml, Parasuraman and Berry (1996), with anchors not at all likely - very likely and items: consider XYZ as a brand option, buy a cell phone made by XYZ company, buy a cell phone made by a competitor of $X Y Z$ company (reverse), recommend to friends and relatives that they buy cell phones made by other brands (reverse).

Besides the involvement with the product items, as described above, other variables were also included as possible moderators: blame attributed to the company due to the problem presented (3 items and Likert scale), involvement with the information read (3 items and Likert scale) and the credibility of the message (one item in a semantic differential scale). All of them were adapted from Pullig (2000).

\section{Results}

The sample obtained was composed of a total of 91 participants, considering the groups product news $(n=30)$, company news $(n=30)$ and no news $(n=31)$.

Manipulation Checks. Following the recommendation of Perdue and Summers (1986), the final section of the questionnaire evaluated the participant's interpretation of the stimulus through the use of three questions. The first was a dichotomous question that asked if the information referred to a product defect or to the conduct of the company. The following two questions were Likert like, affirming that the news report referred to a specific defect in the company's product while the other affirmed that the news report referred to the company in general and not to a product defect. The answers of the subjects to the first and these last two questions suggested acceptable levels of interpretation $(p<.05)$.

Dimensionality and Reliability. The scales of company image, product image and behavioral intentions were considered unidimensional in the factor analysis, with $\mathrm{KMO}$ values ranging from .522 
(behavioral intentions) to .697 (product image), with significant Bartlett's test of sphericity $(p<.000)$ in all scales, and the following variances explained: 51.8 (product image), 53.3 (company image) and 62.2 (behavioral intentions). Reliability was also in acceptable levels (NUNNALLY, 1967), with the lowest value of .711. Because each scale was unidimensional, a composite score was computed for each one, using the factor score resulting from the factor analysis, which is a common practice in the literature (see MCDONALD, 2001).

$\mathbf{H}_{1}$. This hypothesis predicted that the product news group (EG1) and the company news group (EG2) would present lower averages when compared to the group that received no negative news (control group).

Results presented in table 1 show that the group that received no negative news obtained a higher average (positive) in the three variables of the analysis. The product news group presented negative averages in the three variables, while the company news group showed a negative average in company image and behavioral intentions.

Table 1: Mean Score Comparison for Dependent Variables

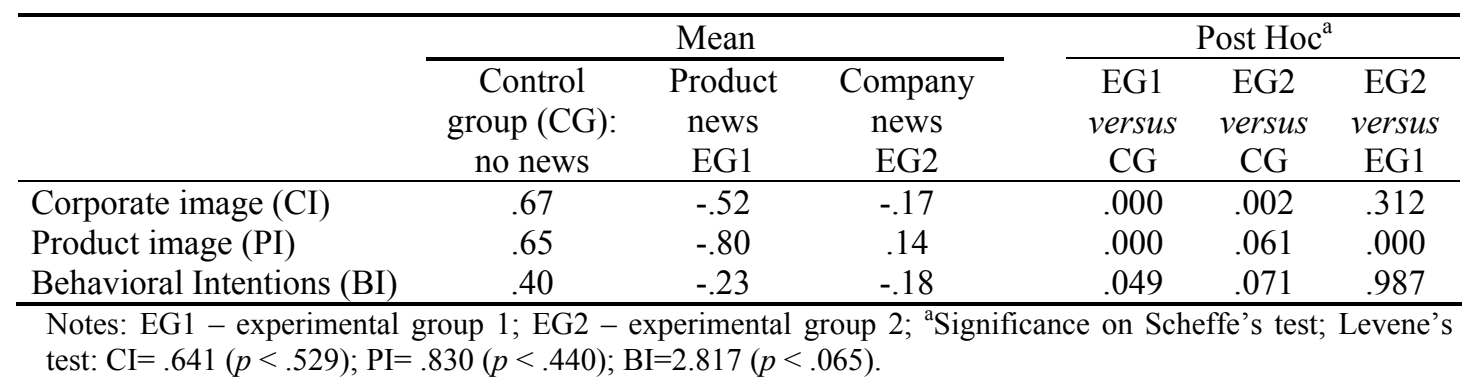

A post hoc analysis tests if these differences are significant, and if so, allows for the identification of the variables in the groups in which they occur. This analysis finds that the corporate image presented a lower score in the product news group in relation to the group that received no news $(p<.000)$. Likewise, the average score in the company news group was also lower when compared to the control group $(p<.002)$. In the same way, product image presented lower average in the product news group $(p<.000)$ and in company news group $(p<.061)$ when compared to the control group. It can still be observed that product image was lower in the product news group in relation to the company news group $(p<.000)$, indicating that the product image was more greatly damaged in the case of news about the product.

The behavioral intentions variable also presented predictable averages, however, there was a significant difference only in the comparison between the product news group and the control group ( $p$ $<.049$ ). The average of this variable in the company news group was not significantly lower than the one in the control group. Therefore, the hypothesis was supported in the company image and product image variables, but only partially supported in the behavioral intentions variable.

$\mathbf{H}_{2}$. The second hypothesis predicts that consumers will have higher involvement with company negative information in relation to product negative information. Results from ANOVA confirmed that involvement with the message was significantly higher in the company information group ( $M_{\text {product }}$ $\left.=-.46 ; M_{\text {company }}=.46 ; F(1,58)=15.917 ; p<.000\right)$. This indicates that the consumer manifested a greater involvement with company information, supporting hypothesis 2 .

Although there were no specific hypotheses about blame associated to the company or credibility of the message, these variables were included for further analyses. Credibility associated to the news report was also greater in the company information group when compared to the product news group $\left(M_{\text {product }}=-.32 ; M_{\text {company }}=.32 ; F(1,56)=6.645 ; p<.013\right)$. So, consumers attributed greater credibility to the news about the company. Blame, on the other hand, was inferior in the company news group 
$\left(M_{\text {product }}=.31 ; M_{\text {company }}=-.31 ; F(1,58)=6.535 ; p<.013\right)$, suggesting that consumers attribute more blame on the company when the negative news is about the product.

$\mathbf{H}_{3}$. The third hypothesis presumes that negative publicity generates lower attitudes in consumers who have lower involvement with the product in comparison to those with a higher involvement. The involvement with the product was not manipulated, only measured, and did not present any significant difference among the three groups, $M_{\text {control }}=-.08 ; M_{\text {product }}=-.10 ; M_{\text {company }}=.19 ; F(2,88)=.814, p<$ .446 , which was an expected consequence of the random assignment of the respondents.

To test this hypothesis, participants were divided into three groups, using the values of percentiles 33 and 66 in the involvement score as cutting points: low involvement (i.e. participants with involvement scores inferior than percentile 33, $n=30$ ), average involvement (i.e. involvement scores between percentile 33 and 66, $n=31$ ) and high involvement (i.e. involvement scores superior than percentile $66, n=30)$. Next, the effects of negative information and involvement on dependent variables were analyzed.

Results from MANOVA indicated a significant effect of negative information (Wilks' lambda = $.590 ; F=5.029 ; p<.000$ ), but not of the involvement (Wilks' lambda $=.900 ; F=1.852 ; p<.150$ ). The interaction was not significant either (Wilks' lambda $=.811 ; F=1.840 ; p<.099$ ). Univariate results show that there is a significant interaction $(p<.040)$ between negative information and involvement in the corporate image variable (see table 2 ).

Table 2: Influence of Negative Information and Product Involvement on Dependent Variables

\begin{tabular}{|c|c|c|c|c|c|c|}
\hline Source & $\begin{array}{c}\text { Dependent } \\
\text { Variable }\end{array}$ & $\begin{array}{l}\text { Sum of } \\
\text { squares }\end{array}$ & $d f$ & $\begin{array}{c}\text { Mean } \\
\text { square }\end{array}$ & $F$ & $p$ \\
\hline \multirow{3}{*}{$\begin{array}{c}\text { Negative } \\
\text { information }\end{array}$} & Corporate image & 14.546 & 2 & 7.273 & 9.993 & .000 \\
\hline & Product image & 19.415 & 2 & 9.708 & 14.566 & .000 \\
\hline & Behavioral intentions & 2.578 & 2 & 1.289 & 1.446 & .245 \\
\hline \multirow{3}{*}{ Involvement } & Corporate image & 1.964 & 1 & 1.964 & 2.699 & .106 \\
\hline & Product image & 2.509 & 1 & 2.509 & 3.764 & .058 \\
\hline & Behavioral intentions & 3.554 & 1 & 3.554 & 3.986 & .051 \\
\hline Negative & Corporate image & 4.974 & 2 & 2.487 & 3.417 & .040 \\
\hline information $\mathrm{x}$ & Product image & 1.286 & 2 & .643 & .965 & .388 \\
\hline Involvement & Behavioral intentions & 1.655 & 2 & .827 & .928 & .402 \\
\hline
\end{tabular}

This interaction, depicted in figure 1, means that: for low involved participants, company image does not differ among the no news, product news and company news groups. For high-involved respondents, on the other hand, there arises a difference $(p<.071)$ between the company news group, whose mean increased, and product news groups, whose mean decreased. Considering high involvement, there is also a difference between product news and no news groups $(p<.020)$, indicating that consumers with high involvement have an even lower score of the corporate image when the product is affected by negative publicity.

In addition to the averages having been higher in the no information (control) group, in this group, the company image increased significantly upon varying from low to high involvement $(p<.002)$. Product image and behavioral intentions were also greater considering high involvement consumers when compared to low involvement in the group that received no information (control group). This indicates that higher involved consumers tend to have higher attitudes. 


\section{Figure 1: Corporate Image by Negative Information and Involvement}

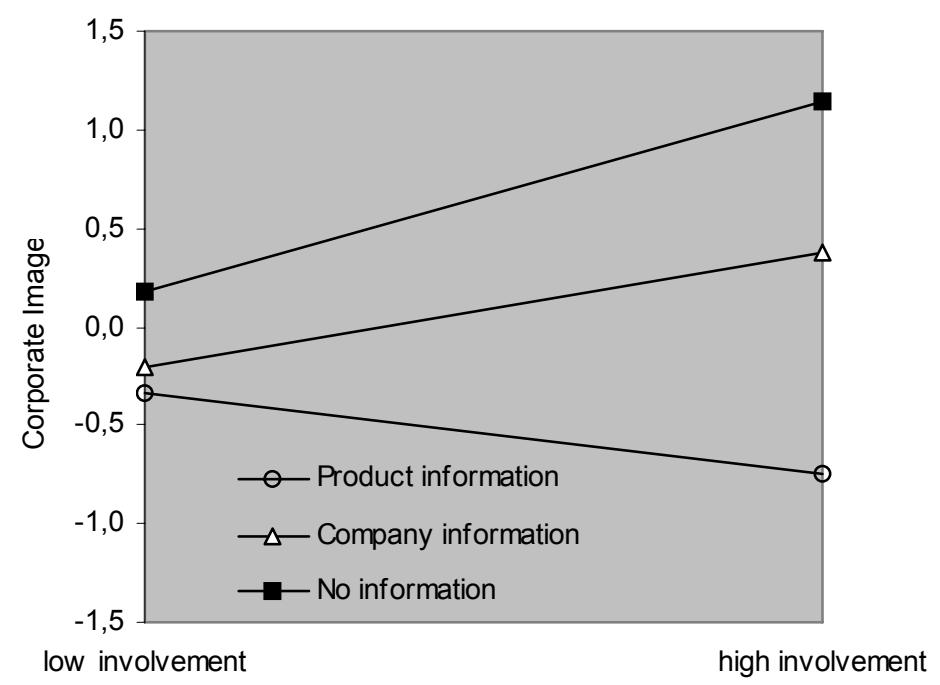

\section{Discussion}

Although research has given heavier weight to negative information in the formation of individual judgments (FISKE, 1980) and the harmful effect of negative publicity on consumer attitudes (AHLUWALIA; BURNKRANT; UNNAVA, 2000; GRIFFIN; BABIN; ATTAWAY, 1991; MENON; JEWEL; UNNAVA, 1999), there is still a gap when referring to the influence of two types of negative publicity related to specific product attributes or to general company values. The existing literature, based mainly on case studies, presents only indications that general company values are perceived as having more relevance to the consumer. This research had the objective of testing this question empirically.

Thus, in a laboratory experiment, negative information was manipulated on two levels: about the product and about the company). To test the hypotheses, the product news and company news groups were compared to a control group (no news). The dependent variable was the consumer attitudes, measured through product image, corporate image and behavioral intentions.

As a result, the harmful effect of negative publicity on consumer attitudes was confirmed: company image, product image and behavioral intentions were lower in the product news group when compared to the no news group but not in the company news group when compared to the no news group, except for the corporate image. These differences were greater in the product no news comparison $(p<.000)$, followed by the company no news contrast. The product-company comparison showed a difference in the product image variable $(p<.000)$. These results indicate that the product news group had the lowest scores in corporate image, product image and behavioral intentions. This group had a score for product image significantly lower than the no news and company news groups. So, we can state that product related negative publicity damages corporate image, product image and behavioral intentions, but company related negative publicity does not have the same effect on the product image and behavioral intentions.

The second hypothesis predicted that negative publicity about a company would generate a higher consumer involvement with the information because it is related to company values and not to specific product attributes. This hypothesis assumed that information linked to company values would have a greater perception of importance by the subject (SKOWRONSKI; CARLSTON, 1989). Involvement with the news was confirmed to be significantly higher in the group that received negative publicity about the company in comparison to the group that received negative publicity about the product. It was also found that consumers associated greater credibility to a company related news, when compared to the product news, and that consumers place more blame on the company when the 
problem is related to the product. Thus, negative publicity related to the product is more often associated with the company responsibility by the consumers than are problems involving values or conduct.

In the third hypothesis, we attempted to identify a moderator effect of the involvement with the product, which refers to the importance that subjects attribute to the cell phone. In the literature on consumer behavior, involvement is seen as an influential factor in the process of persuasion and attitude change (PETTY; CACIOPPO, 1981). This hypothesis predicted that negative publicity would generate lower attitudes for those consumers with lower involvement, because consumers with higher involvement would argue against the negative publicity in order to defend the company. A significant interaction $(p<.040)$ emerged between negative information and product involvement on corporate image, meaning that for low involved respondents there is no difference of corporate image score between the experimental groups. However, for high-involved participants, those who received a negative publicity related to the product rated the corporate image lower than those who had received a negative publicity related to the company. Actually, while there was an improvement in the score of corporate image when considering company negative information (low involvement $\rightarrow$ high involvement), the opposite was true for the condition of product negative information.

Based on these results, it can be argued that consumers with low involvement do not resist persuasion from negative news, as predicted in the literature, and give low ratings to corporate image, regardless of whether the news is about the product or the company. On the other hand, considering high involvement consumers, those who receive news about a product give even lower marks while the consumer that reads news about the company becomes more resistant to persuasion. Previous studies predict that in situations of high involvement, there is a greater resistance to persuasion. The results found here suggest that there is another moderating variable which is the nature of the negative publicity: company-values related negative publicity is seen as more general and produces resistance to persuasion, but those more related to product attributes do not generate resistance to persuasion, maybe because these last ones are more difficult to oppose. In summary, negative publicity about the product affects both the product image and the corporate image, and those subjects with high involvement have an even lower level of perceived corporate image.

\section{EXPERIMENT 2}

The previous experiment indicates that consumer reactions to negative publicity are different depending on whether it is more related to the product (ability domain) or to the company (values domain). Even though the effects of negative publicity on consumer attitudes have been examined (e.g. AHLUWALIA et al., 2000), these two categories have not been investigated in combination with the responses to the event, as recognized by Dean (2004).

In order to test if any of the response strategies suggested in the literature could attenuate the harmful effect of the negative publicity, a second experiment was prepared. According to Benoit (1997), when dealing with negative publicity, companies can (i) deny the problem (denial), (ii) refuse to take responsibility for the problem (evasion of responsibility), (iii) claim that the problem is not as bad as it may seem to be (reduction of offensiveness), (iv) recognize the problem and present measures to correct it (corrective action) or (v) apologize for the problem (embarrassment).

\section{Method}

Design. A between-subjects factorial experiment was conducted manipulating negative publicity at two levels (product and company) and company response at four levels (no answer, denial, reduction of offensiveness and corrective action), with dependent variables being measured only after the stimulus. The product and brand affected by negative publicity were the same as in the first experiment. This second study adopted a non-probabilistic quota sample. 
Stimuli and procedure. Subjects were interviewed in the streets of a Brazilian capital, in the proximity to shopping malls and squares, and they were randomly assigned to one of the eight experimental groups. A final sample of 266 participants was obtained. The stimuli used for the negative information were the same as in the first experiment. The news presented as responses were adapted from the real responses used by the company in such a way as to be interpreted as (i) denial of the problem; (ii) claim that the problem was not as bad as it seemed; (iii) corrective action to resolve the problem. These three reaction alternatives were chosen as being the most representative of the Benoit (1997) typology. Dependent variables were the same as in the first experiment.

\section{Results}

Manipulation Checks. Two questions were used for the negative information. As expected, the question asserting that the problem presented was related to a specific defect in the product obtained a higher agreement in the product news group: $M_{\text {product }}=5.35 ; M_{\text {company }}=2.76 ; F(1,264)=96.045, p<$ .000 . In the same way, the question claiming that the problem presented was related to the company in general had more agreement in the company news group: $M_{\text {product }}=3.00 ; M_{\text {company }}=4.71 ; F_{1,263}=$ $35.793, p<.000$.

Three other Likert like questions were used to evaluate whether the company response was as predicted. The first, which affirmed that the company response appeared to be an attempt to deny the problem, obtained, contrary to expectations, a higher average in the reduction of offensiveness group: $M_{\text {deny }}=3.96 ; M_{\text {reduction }}=4.97 ; M_{\text {corrective }}=2.45 ; F_{2,197}=22.473, p<.000$, with all contrasts being significant in the post-hoc test (Scheffé). This was surprising because in the pre-test stage the same message used for reduction of offensiveness suggested a significant difference from the others.

The second, which affirmed that the company response was an attempt to show that the problem was not as bad as it seemed obtained averages in the expected direction: $M_{\text {deny }}=4.15 ; M_{\text {reduction }}=5.92$; $M_{\text {corrective }}=3.18 ; F_{2,197}=29.585, p<.000$.

The third, which affirmed that the company response was an attempt to correct the announced problem, also obtained averages in the expected directions: $M_{\text {deny }}=5.28 ; M_{\text {reduction }}=3.83 ; M_{\text {corrective }}=$ $6.03 ; F_{2,197}=17.792, p<.000$.

Due to this lack of understanding by the research subjects between these two company reactions (denial and reduction of offensiveness), these two groups were considered only one being named 'reduction of offensiveness', because subjects understood that this reaction would mean a 'denial of the problem' and also its theoretical original meaning (i.e. that the problem was not as bad as it seemed). This remedy of joining these groups can be considered the least problematic (MALAVIYA, 2003) because others would imply serious constraints. For example, classifying the respondents on the basis of their answers given in the manipulation checks would cause the loss of the random assignment; excluding subjects based in the answer in the manipulation checks would result in drastic reduction of some groups (i.e., denial group would stay with only 14 subjects, i.e. 8 in the product and 6 in the company related negative publicity). Also, any criteria for exclusion would be arbitrary because manipulation checks questions were Likert like (i.e., a continuum). After this consideration and decision, the number of respondents ranged from 32 to 69 in each group.

Dimensionality and Reliability. As in the first experiment, reliability statistics were in acceptable levels (i.e. minimum of .701, for company image) and all the scales used were unidimensional, with KMO values ranging from .595 (behavioral intentions) to .751 (product image), and variances explained varying from 55.7 (product image) to 82.8 (behavioral intentions). Based on these results, factor scores were computed for each scale and used in the subsequent analysis.

Analysis of Variance. Analysis of variance was performed to evaluate the influence of negative information and company reaction on company image, product image and behavioral intentions, initially with the multivariate version (MANOVA) and then including the involvement with the product as a controlled variable (MANCOVA). 
Results from MANOVA showed that negative information does not present a significant influence in the combination of the dependent variables (Wilks' lambda $=.993 ; F=.635 ; p<.593$ ), although the company reaction does (Wilks' lambda $=.934 ; F=2.961 ; p<.008$ ). There is also a significant interaction between negative information and reaction if we consider a $10 \%$ confidence level (Wilks' lambda $=.957 ; F=1.875 ; p<.083)$.

According to the results of the univariate analysis of variance (see table 3 ), the interaction is significant only on product image $(p<.035)$.

Table 3: Univariate Effects of the Experimental Factors on Dependent Variables

\begin{tabular}{clccccc}
\hline Source & \multicolumn{1}{c}{$\begin{array}{c}\text { Dependent } \\
\text { variable }\end{array}$} & $\begin{array}{c}\text { Sum of } \\
\text { squares }\end{array}$ & $d f$ & $\begin{array}{c}\text { Mean } \\
\text { square }\end{array}$ & $F$ & $p$ \\
\hline Negative information & Corporate image & .176 & 1 & .176 & .225 & .636 \\
& Product image & .950 & 1 & .950 & 1.230 & .268 \\
& Behavioral Intentions & .0318 & 1 & .0318 & .043 & .836 \\
\hline \multirow{2}{*}{ Reaction } & Corporate image & 6.919 & 2 & 3.460 & 4.432 & .013 \\
& Product image & 2.706 & 2 & 1.353 & 1.751 & .176 \\
& Behavioral Intentions & 1.133 & 2 & .566 & .765 & .466 \\
\hline Negative information & Corporate image & 1.318 & 2 & .659 & .844 & .431 \\
& Product image & 5.229 & 2 & 2.615 & 3.384 & .035 \\
Reaction & Behavioral Intentions & .970 & 2 & .485 & .655 & .520 \\
\hline
\end{tabular}

Note: Levene's test: Corporate image: $F=2.302(p<.045)$, product image: $F=2.268(p<.048)$, behavioral intentions: $F=2.033(p<.074)$.

This significant interaction in the product image variable, depicted in figure 2, is due to: (i) for negative information about the product, there is a significant difference $\left(F_{2,126}=3.539 ; p<.032\right)$ in this variable when comparing corrective action with no answer $(p<.068)$ and reduction of offensiveness with no answer $(p<.063)$. The non-parametric test of Kruskal-Wallis suggested a similar interpretation: $\chi^{2}=5.853 ; p<.054$ ); (ii) when the negative information is about the company, however, there is no difference between the groups in the product image variable $\left(F_{2,132}=1.455 ; p<.237\right)$.

Based on figure 2, it can be noted that corrective action and reduction of offensiveness groups have negative scores on product image variable, when the negative information is product related. As presented above, this difference is significant when compared to the no answer group. However, when considering negative information about the company, these scores become positive, even though with no significant difference among them. So, this result suggests that corrective action was not able to attenuate the negative attitude caused by the negative publicity about the product, neither was the reduction of offensiveness. This debate is resumed in the discussion section. 


\section{Figure 2: Product Image by Negative Information and Company Reaction}

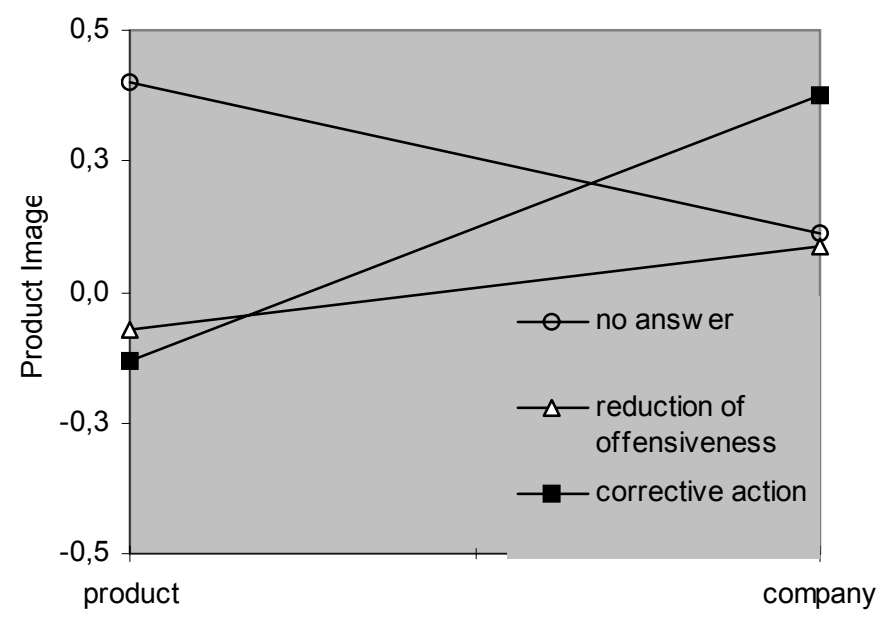

In order to analyze more closely the effects of the involvement with the product in the relations between negative publicity and company reaction on consumer attitudes, the sample was split out in two groups, using the median as the cut point: low involvement $(n=125)$ and high involvement $(n=141)$. Next, analysis of variance was performed using involvement as a factor together with negative information and company reaction and the same dependent variables as before.

Multivariate results suggest an interaction between involvement and reaction (Wilks' lambda $=.950$; $F=2.175 ; p<.044$ ), with the univariate results indicating that this interaction was more salient on the product image variable, for which $p<.013$ (see Figure 3 ).

This interaction is a result of this pattern: for consumers with low involvement, there are significant differences $\left(F_{2,121}=4,100 ; p<.019\right)$ among the company reaction options, especially comparing corrective action with no answer $(p<.045)$ and reduction of offensiveness with no answer $(p<.030)$. However, there are no differences of these types of company reaction for consumers with high involvement $\left(F_{2,137}=1.963 ; p<.144\right)$. 
Figure 3: Product Image by Involvement and Company Reaction

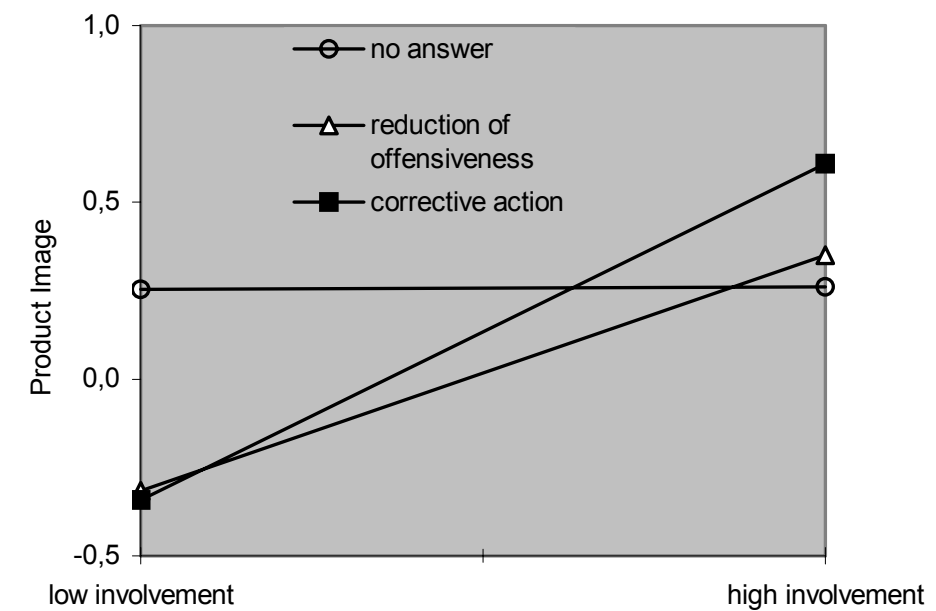

\section{General Discussion and Conclusion}

Departing from the results of experiment 1, which revealed different effects of the two types of negative information on the dependent variables investigated, a new experiment was conducted with the objective of testing distinct company reactions (BENOIT, 1997) toward the two types of negative publicity previously investigated. Thus, two factors were manipulated in a field experiment: negative publicity and company response.

While the first experiment suggested that product image is more affected when the negative information is related to the product and its attributes, the second experiment indicates a significant interaction between negative information and company reaction on product image, meaning that none of the response strategies investigated, neither corrective action nor reduction of offensiveness, could cancel the negative perception of the product (i.e. both experimental groups had significantly lower means when compared to the control group, no answer).

Furthermore, when involvement was included in this model, the same pattern was found (i.e. that the reactions were not successful in canceling the negative effects of a product related information in the perceived product image), but this was valid only for low involved consumers. These results reinforces the importance of involvement once again and indicates that not only are the effects of a product related negative publicity more harmful for the perceived product image, but also that company reactions are not able to attenuate the problem, especially considering low involved consumers.

These results contribute to the marketing literature by testing the moderating effects of the involvement variable, as previous studies have already shown (e.g. PETTY; CACIOPPO, 1981), and also by testing empirically some company reactions alternatives that are presented in the related literature (BENOIT, 1997), but that are mainly based on case studies and qualitative inquiries.

In their studies, Ahluwalia, Burnkrant and Unnava (2000) also tested the possibility of the moderator effect, but in this case using a consumer commitment variable considered as being similar to brand loyalty. As this concept is different from the involvement with the product, even though they may be correlated (POIESZ; DE BONT CEES, 1995), the results of this moderation cannot be directly compared. In general, Ahluwalia and her colleagues also found that highly involved consumers instinctively argue against negative information about the brand. However, these authors consider only product-related negative information. So, the presented studies also extend these findings by including another type of negative publicity, which is the company-values related. 
Skowronski and Carlston (1987) suggest that negative information linked to moral aspects (e.g. company values) is perceived as more important when compared with negative information related to aspects of company ability (e.g. product attributes), as it was really found in the results of the first experiment. This study also showed that when the negative information is in the values domain, the perceived product image is not affected. In accordance with these results, the second experiment found that there was no significant difference among the company response alternatives on the perceived product image when the negative message was in the values domain (i.e. company related).

Although the second experiment was in the field, and then could be considered high in external validity (CAMPBELL; STANLEY, 1963), it was also taken into account the effects of some other factors, such as gender, age and level of education, which were balanced in the quota sample. Thus, by controlling these variables and including others in the analysis (e.g. involvement), the external validity could be enhanced (LYNCH, 1999).

The results presented can also contribute with implications for managers, especially those in Public Relations responsible for elaborating messages in crisis situations. It should particularly be noticed that consumers process negative information in different ways, depending on the aspects of the message (i.e. more product or company related) and the level of involvement of the consumer (low $x$ high), as it was investigated in this paper. Consumers give more importance to the message when it is in the values domain, but the message in the attributes domain affects both the perceived product image and corporate image. In general, when consumers are low involved with the product in question, the negative message is more harmful for their perceptions (i.e. they do not oppose the negative information) and in this case even the company response (usually in the positive framing) can also be processed in the peripheral route (PETTY; CACIOPPO, 1981) and then be discarded. Thus, companies could try to improve consumers' involvement with their product, increasing the associated importance of the product for the consumer, and also with their brands, taking advantage of the brand loyalty benefits (FOURNIER, 1998).

The limitations of the study must be taken into account. First of all, only one brand and one class of products was investigated in both studies. Future studies could also include other categories of products or even services, as well as other brands. Moreover, both experiments manipulated negative information published in newspapers. New studies may try to extend the results for different media (e.g. TV, radio or even word-of-mouth communication among the consumers). Also, subjects in the field experiment were not able to distinguish between two manipulations of company reaction (i.e. denial and reduction of offensiveness), as showed by the manipulation checks analysis. This was surprising because pretests had showed before that consumers perceived the denial response as a rejection of the problem by the company and the reduction of offensiveness response as a minimization of the problem by the company, exactly as stated in the literature. New studies could focus on whether or not this theoretical difference is really perceived by consumers. Finally, involvement with the product was not manipulated. Thus in future research one might also consider varying situations of high and low consumer involvement as well as taking into account the effects of other variables that could influence the results and thus obtain further support for the external validity of the results here presented (WINNER, 1999).

Artigo recebido em 27.11.2004. Aprovado em 07.03.2005.

\section{REFERENCES}

AHLUWALIA, R.; BURNKRANT, R. E.; UNNAVA, H. R. Consumer response to negative publicity: the moderating role of commitment. Journal of Marketing Research, Chicago, v. 37, n. 2, p. 203214, may 2000. 
BAGOZZI, R., GÜRHAN-CANLI, Z.; PRIESTER, J. R. The Social Psychology of Consumer Behavior. 1 th ed. Buckingham, UK: Open University Press, 2002. p. 222.

BENOIT, W. L. Image repair discourse and crisis communication. Public Relations Review, Amsterdam, Netherlands, v. 23, n. 2, p. 177-186, Summer 1997.

CAMPBELL, D. T.; STANLEY, J. C. Experimental and quasi-experimental designs for research. 1 th ed. Chicago, USA: Rand McNally, 1963. p. 84

CELSI, R. L.; OLSON, J. C. The Role of Involvement in Attention and Comprehension Processes, Journal of Consumer Research, Chicago Illinois, USA, v. 15, n. 2, p. 210-224, sept. 1988.

DEAN, D. H. Consumer Reaction to Negative Publicity. Journal of Business Communication, New York, USA, v. 38, n. 2, p. 192-211, apr. 2004.

EAGLY, A. H.; CHAIKEN, S. The Psychology of Attitudes. 1 th ed. Fort Worth, TX: Harcourt Brace Jovanovich, 1993. p. 800

FISHBEIN, M.; AJZEN, I. Belief, attitude, intention, and behavior: an introduction to theory and research. 1 th ed. Reading, MA: Addison-Wesley, 1975. p. 578.

FISKE, S. T. Attention and weight in person perception: the impact of negative and extreme behavior. Journal of Personality and Social Psychology, Washington District of Columbia, USA, v. 38, n. 6, p. 889-906, june 1980.

FOURNIER, S. Customers and Their Brands: Developing Relationship Theory in Consumer Research. Journal of Consumer Research, Chicago Illinois, USA, v. 24, n. 4, p. 343-373, mar. 1998.

GRIFFIN, M.; BABIN, B. J.; ATTAWAY, J. S. An empirical investigation of the impact of negative publicity on consumer attitudes and intentions. Advances in Consumer Research, Provo, UT: Association for Consumer Research, v. 18, n. 1, p. 334-341, 1991.

JAIN, K.; SRINIVASAN, N. An Empirical Assessment of Multiple Operationalizations of Involvement, Advances in Consumer Research, Provo, UT: Association for Consumer Research, v. 17, n. 1, p. 594-602, Summer 1990.

JAMES, W. L.; SONNER, B. S. Just say no to traditional student samples. Journal of Advertising Research, Cambridge, UK, v. 41, n. 5, p. 63-71, sept./oct. 2001.

LAURENT, G.; KAPFERER, J. N. Measuring Consumer Involvement Profiles. Journal of Marketing Research, Chicago Illinois, USA, v. 22, n. 1, p. 41-53, feb. 1985.

LYNCH JR, J. G. Theory and external validity. Journal of the Academy of Marketing Science, Coral Gables Florida, USA, v. 27, n. 3, p. 367-376, Summer 1999.

MAHESWARAN, D.; MEYERS-LEVY, J. The influence of message framing and issue involvement. Journal of Marketing Research, Chicago Illinois, USA, v. 27, p. 361-67, aug. 1990.

MAHESWARAN, D.; STERNTHAL, B. The effects of knowledge, motivation, and type of message on ad processing and product judgments. Journal of Consumer Research, Chicago Illinois, USA v. 17, n. 1, p. 66-73, june 1990.

MALAVIYA, P. Question Message from electronic mail: prashant.malaviya@insead.edu in 23 dec. 2003. 
McDONALD, R. Measurement. Journal of Consumer Psychology, Mahwah New Jersey, USA, v. 10, n. 1-2, p. 55-69, jan. 2001.

MENON, G.; JEWELL, R. D.; UNNAVA, H. R. When a company does not respond to negative publicity: cognitive elaboration vs. negative affect perspective. Advances in Consumer Research, Provo, UT: Association for Consumer Research, v. 26, n. 1, p. 325-29, Fall 1999.

MIZERSKI, R. W. An attributional explanation of the disproportionate influence of unfavorable information. Journal of Consumer Research, Chicago Illinois, USA, v. 9, n. 3, p. 301-10, dec. 1982.

NUNNALlY, J. C. Psychometric Theory. 1 th ed. New York, USA: McGraw-Hill, 1967. p. 640.

PERDUE, B. C.; SUMMERS, J. O. Checking the success of manipulations in marketing experiments. Journal of Marketing Research, Chicago Illinois, USA, v. 23, n. 4, p. 317-26, nov. 1986.

PETTY, R. E.; CACIOPPO, J. T. Attitudes and Persuasion: classic and contemporary approaches. 1 th ed. Dubuque, Iowa, WCB, 1981. p. 314.

POIESZ, T. B. C.; CEES, J. P. M de BONT. Do we need involvement to understand consumer behavior? Advances in Consumer Research, Provo, UT, Association for Consumer Research, v. 22, n. 1, p. 448-52, Summer, 1995.

PULLIG, C. P. The Effects of Negative Events and Firm Responses on Brand Associations, Organizational Associations, and Brand Evaluations 2000. 275f. Dissertation. (Doctoral of Philosophy in the Interdepartamental Program in Business Administration) - Faculty of the Louisiana State University, United States. UMI no 9979286.

REIDENBACH, R. E.; FESTERVAND, T. A.; MACWILLIAM, M. Effective corporate response to negative publicity. Business, [S.1.], v. 37, n. 4, p. 9-17, oct./dec. 1987.

SKOWRONSKI, J. J.; CARLSTON, D. E. Social judgment and social memory: the role of cue diagnosticity in negativity, positivity, and extremity biases. Journal of Personality and Social Psychology, Washington District of Columbia, USA, v. 52, n. 4, p. 689-699, apr. 1987.

. Negativity and extremity biases in impression formation: a review of explanations. Psychological Bulletin, Washington District of Columbia, USA, v. 105, n. 1, p. 131-142, jan. 1989.

WINNER, R. S. Experimentation in the $21^{\text {st }}$ century: the importance of external validity. Journal of the Academy of Marketing Science, Coral Gables Florida, USA, v. 27, n. 3, p. 349-358, Summer, 1999.

ZAICHKOWSKY, J. L. Measuring the involvement construct. Journal of Consumer Research, Chicago Illinois, USA, v. 12, n. 3, p. 341-352, dec. 1985.

ZAJONC, R. B.; MARKUS, H. Affective and cognitive factors in preferences. Journal of Consumer Research, Chicago Illinois, USA, v. 9, n. 2, p. 123-131, sept. 1982.

ZEITHAML, V. A.; PARASURAMAN, A.; BERRY, L. L. The behavioral consequences of service quality. Journal of Marketing, Chicago Illinois, USA, v. 60, n. 2, p. 31-43, apr. 1996. 